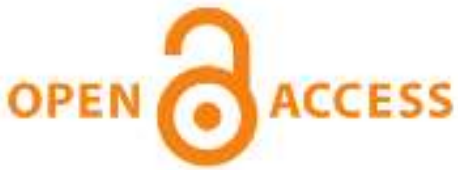

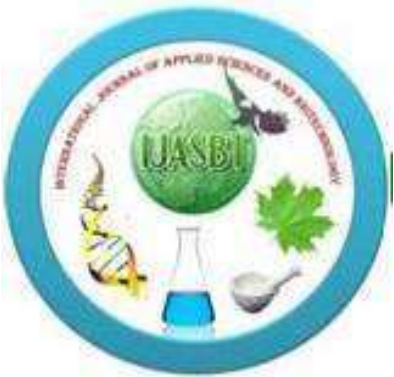 \\ International Journal of Applied Sciences and Biotechnology
}

\author{
A Rapid Publishing Journal
}

ISSN 2091-2609

\section{Indexing and Abstracting}

CrossRef, Google Scholar, Global Impact Factor, Genamics, Index Copernicus, Directory of Open Access Journals, WorldCat, Electronic Journals Library (EZB), Universitätsbibliothek Leipzig, Hamburg University, UTS (University of Technology, Sydney): Library, International Society of Universal Research in Sciences (EyeSource), Journal Seeker, WZB, Socolar, BioRes, Indian Science, Jadoun Science, JourInformatics, Journal Directory, JournalTOCs, Academic Journals Database, Journal Quality Evaluation Report, PDOAJ, Science Central, Journal Impact Factor, NewJour, Open Science Directory, Directory of Research Journals Indexing, Open Access Library, International Impact Factor Services, SciSeek, Cabell's Directories, Scientific Indexing Services, CiteFactor, UniSA Library, InfoBase Index, Infomine, Getinfo, Open Academic Journals Index, HINARI, etc.

\section{CODEN (Chemical Abstract Services, USA): IJASKD}
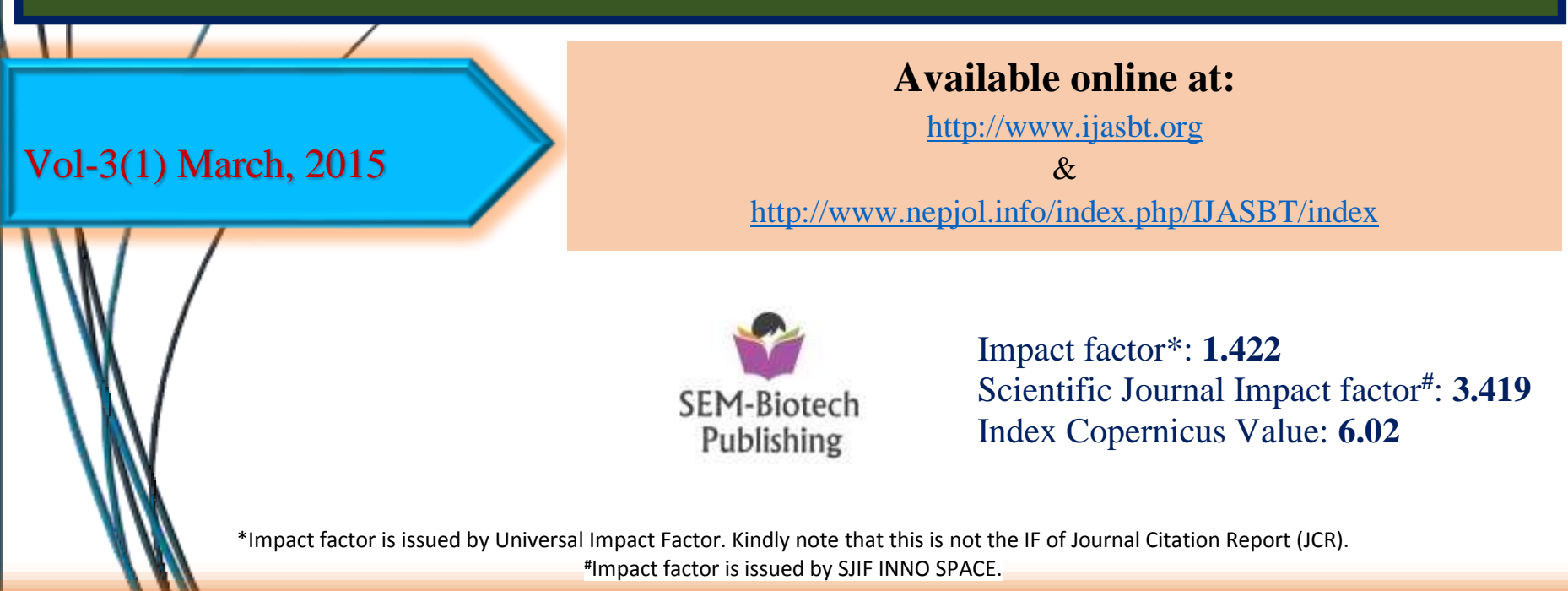

Impact factor*: $\mathbf{1 . 4 2 2}$

Scientific Journal Impact factor": 3.419

SEM-Biotech

Publishing

Index Copernicus Value: $\mathbf{6 . 0 2}$

*Impact factor is issued by Universal Impact Factor. Kindly note that this is not the IF of Journal Citation Report (JCR). 


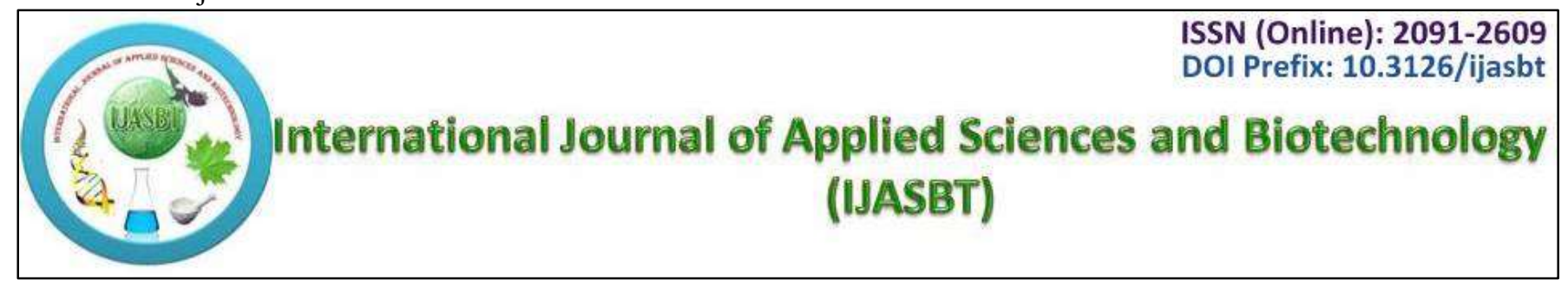

Research Article

\title{
STATUS OF THYROID DISORDERS IN CENTRAL NEPAL: A TERTIARY CARE HOSPITAL BASED STUDY
}

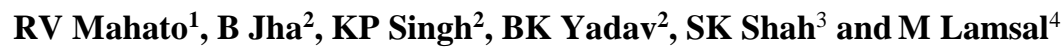 \\ ${ }^{1}$ Tribhuvan University, Institute of Science and Technology, Central Campus of Technology, Dharan, Nepal. \\ ${ }^{2}$ Tribhuvan University, Institute of Medicine, Department of Biochemistry TUTH, Nepal \\ ${ }^{3}$ Asian College for Advanced studies, Department of Medical Laboratory Technology,Lalitpur, Nepal. \\ ${ }^{4}$ BP Koirala Institute of Health Science, Department of Biochemistry, Dharan Nepal \\ Corresponding author's email: ramvinodmahato42@gmail.com
}

\begin{abstract}
Background: Nepal is a Himalayan, landlocked country surrounded by India and China. It is endemic for iodine deficiency disease. Thyroid dysfunction is major health problem among the Nepalese people. Its prevalence increases with age. Screening of thyroid disease is advised in high risk population. Objectives: To find out the prevalence of thyroid dysfunction among subjects who attended Biochemistry Department of Tribhuwan University Teaching Hospital, Kathmandu, Nepal. Material and Methods: This is a hospital based retrospective study conducted in the Department of Biochemistry Tribhuwan University Teaching Hospital, Institute of Medicine. This study was designed to investigate status of thyroid dysfunction in central Nepal. A total of 5230 cases from all over Nepal were studied in a single year. Blood samples were collected, serum separated and thyroid hormones ( $\mathrm{fT}_{3}, \mathrm{fT}_{4}$ and $\mathrm{TSH}$ ) were assayed by Vitros ECIQ analyser Ortho Clinical Diagonostics USA. Result and discussion: Among 5230 subjects prevalence of thyroid dysfunction was $29.0 \%$ with subclinical hypothyroidism $17 \%$, hypothyroidism $8 \%$, hyperthyroidism $3 \%$, subclinical hyperthyroidism $1 \%$ and euthyroidism $71 \%$. Higher prevalence was seen in the age group 31-45. Conclusion: This study revealed that subclinical and overt hypothyroidism is preponderant followed by sub clinical hyperthyroidism. Females are more vulnerable to the thyroid dysfunction. Since it is a hospital based study, the prevalence of thyroid dysfunction may not be applicable. So an extensive demographic survey should be done to provide accurate data of thyroid dysfunction in the general population.
\end{abstract}

Keywords: Thyroid Disorders; iodine deficiency; hypothyroidism

\section{Introduction}

Alteration of Thyroid Stimulating Hormone (TSH) with normal or abnormal freeT3 and free T4 hormone indicates thyroid dysfunction (Peter, 2009) Thyroid disorder along with goiter is one of the major health problems in the eastern part of Nepal (Ashworth et al., 1996). It has been estimated that $0.2 \%$ of the deaths in Nepal results from endocrine disorder. Among which iodine deficiency has been major cause (World Health Organization., 2001).Different factors associated with thyroid dysfunction, congenital factors, and genetic predisposition, inadequate iodine intake, pregnancy, viral infections, radiotherapy, surgery, autoimmunity (Vanderpump et al., 2002; Wiersinga et al., 1995; Brownlie et al., 1990). The prevalence of hyperthyroid (13.68\%), hypothyroidism (17.19\%) in eastern Nepal (Helfand et al., 998) and $17.42 \%$ in western Nepal( Risal et al., 2010 ).The prevalence of thyroid dysfunction, by definition is the testing of the patients in various geographical regions, primary care clinics and in population that have not been screened previously(Parle et al., 1992; Friedman et al., 1999).American thyroid association recommended that adults be screened for thyroid dysfunction by measuring serum thyrotropin concentration beginning at the age of 35 and every 5 years thereafter(Ladenson et al., 2000).Nepal is one of the high risk populations with its high prevalence of iodine deficiency disorder(. Gelal et al., 2009).Though the prevalence of thyroid dysfunction has been studied in eastern and western part of Nepal. This is the first study to assess the prevalence of thyroid dysfunction in the central region of Nepal. The study was designed to study different thyroid disorders prevalent in patients visiting department of Biochemistry, Tribhuwan University Teaching Hospital (TUTH) Kathmandu, Nepal.

\section{Materials and Methods}

This retrospective study was conducted in Department of Biochemistry, Tribhuvan University Teaching Hospital Kathmandu Nepal from January 2010 to December 2010.Total 5230 patients visiting Biochemistry Laboratory for thyroid function tests were included in this study. Duplication of persons involved in follow up was excluded; 
ethical clearance was taken as per the guidelines of the research Unit of Institute of Medicine.

\section{Collection of Blood Samples}

Venous blood sample $(2-3 \mathrm{ml})$ was collected from antecubital vein in a plain vial, and was allowed to clot, then subsequently serum was separated by centrifugation at 3000 $\mathrm{g}$ for 10 minutes and stored at $-20{ }^{\circ} \mathrm{C}$ until thyroid hormones were estimated.

\section{Assay procedure of thyroid hormones}

The thyroid hormones $\left(\mathrm{fT}_{3}, \mathrm{fT}_{4}\right.$ and $\mathrm{TSH}$ ) were assayed by Vitros ECIQ analyser Ortho Clinical Diagonostics. The reference range used for $\mathrm{fT}_{3}$ was $1.21-4.18 \mathrm{pg} / \mathrm{mL}$, for $\mathrm{fT}_{4}$ were 7.2-17.2 pg/ $\mathrm{mL}$ and for TSH was 0.6-4.5 $\mu \mathrm{IU} / \mathrm{mL}$. Thyroid function was considered normal (Euthyroidism) when subjects had all the three hormones within the reference range. Abnormal thyroid function was further categorized as hyperthyroidism (increased $\mathrm{FT}_{3}$, $\mathrm{FT}_{4}$ and low $\mathrm{TSH}$ below the normal level), subclinical hyperthyroid (both $\mathrm{FT}_{3}$ and $\mathrm{FT}_{4}$ are normal but $\mathrm{TSH}$ lower), hypothyroidism (decreased $\mathrm{FT}_{3}, \mathrm{FT}_{4}$ and increased $\mathrm{TSH}$ ) and subclinical hypothyroidism $\left(\mathrm{FT}_{3}, \mathrm{FT}_{4}\right.$ are normal but elevated TSH level) (Peter, 2009; Helfand and Redfern, 1998).

\section{Statistical Analysis}

The data entered in MS Excel 2007 and analyzed by Statistical package for Social Science (SPSS) version 16.0 (SPCC Inc. Chicago). Descriptive and inferential statistics were applied. Data were presented as frequency and Mean \pm SD. Normality test was done using Komolovsmrinov test. Student's' test was applied for parametric data. Chi Square test was applied for the comparison of non-parametric qualitative variables. $\mathrm{P}$ value $<0.05$ was considered statistically significant.

\section{Results}

In this study total 5230 subjects were enrolled from January 2010 to December 2010.Among these subjects $32.10 \%$ were male and $67.90 \%$ were females. Majority of the subjects who visited TUTH for thyroid hormone investigation were female. In this study subjects are divided according to the thyroid status which shows subclinical hypothyroidism 885(17\%) hypothyroidism 396(8\%), hyperthyroidism134 (3\%), subclinical hyperthyroidism $75(1 \%)$ and euthyroidism $3740(71 \%)$ as shown in Fig 1 pie chart.

Overall prevalence of thyroid disorder was found to be 29.0 with subclinical hypothyroidism being the most common $17.0 \%$. Table 1. Shows most of the patients were in the age group 31-45( $\mathrm{N}=522)$ followed by $16-30$ years age group $(\mathrm{N}=398), 46-60(\mathrm{~N}=301)$.More Subclinical hypothyroidism (23.1\%) 71 and hypothyroidism(14.7\%) 45 cases were seen in less than 15 year of age group and the decreasing trends of prevalence was seen with increasing age. Prevalence of pituitary defect was similar in $\leq 15$ and $\geq 61$ age groups $(0.2 \%$ and $0.3 \%)$. Table 2 shows the comparison of thyroid hormone level among various thyroid dysfunctions. The ANOVA test was applied to check the significant difference of variables between each group.fT3, ft4 and TSH shows significant difference among different thyroid disorder.

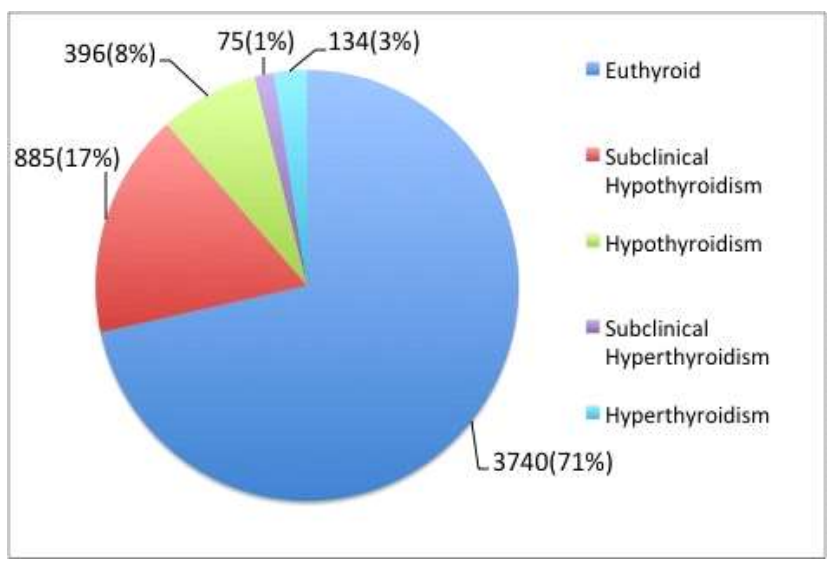

Fig 1: Distribution of different thyroid disorders

Table 3 shows the comparison of thyroid hormones between male and female. Males $(2.43 \pm 1.44)$ have significantly lower level of $\mathrm{ft} 3$ and $\mathrm{ft} 4$ hormones than females $(2.6 \pm 1.77)$ in our study. ( $p$ value $<0.05$ ). But there is no significant difference in the TSH level between male and female.

Table 1: Distribution of different thyroid disorders according to age groups

\begin{tabular}{|l|l|l|l|l|l|}
\hline \multirow{2}{*}{ Thyroid status } & \multicolumn{5}{|c|}{ Age Groups } \\
\cline { 2 - 6 } & $\leq 15$ & $16-30$ & $31-45$ & $46-60$ & $\geq 61$ \\
\hline Normal & $183((59.6 \%)$ & $1062(72.7 \%)$ & $1319(71.6 \%)$ & $768(71.8 \%)$ & $395(71.6 \%)$ \\
\hline Subclinical Hypothyroidism & $71(23.1 \%)$ & $254(17.4 \%)$ & $318(17.3 \%)$ & $162(15.2 \%)$ & $80(14.5 \%)$ \\
\hline Hypothyroidism & $45(14.7 \%)$ & $82(5.6 \%)$ & $126(6.8 \%)$ & $92(8.6 \%)$ & $50(9.1 \%)$ \\
\hline Subclinical Hyperthyroidism & $3(1.0 \%)$ & $17(1.2 \%)$ & $27(1.5 \%)$ & $17(1.6 \%)$ & $11(2.0 \%)$ \\
\hline Hyperthyroidism & $4(1.3 \%)$ & $40(2.7 \%)$ & $48(2.6 \%)$ & $27(2.5 \%)$ & $15(2.7 \%)$ \\
\hline Pituitary defect & $1(0.3 \%)$ & $5(0.3 \%)$ & $3(0.2 \%)$ & $3(0.3 \%)$ & $1(0.2 \%)$ \\
\hline Total & 307 & 1460 & 1841 & 1069 & 552 \\
\hline \hline
\end{tabular}


Table 2: Represents comparison of thyroid hormone levels among various thyroid dysfunction levels.

\begin{tabular}{|l|l|l|l|l|l|l|l|}
\hline $\begin{array}{l}\text { Thyroid } \\
\text { Hormones }\end{array}$ & $\begin{array}{l}\text { (Mean } \pm \text { E) } \\
\text { Euthyroidism }\end{array}$ & $\begin{array}{l}\text { (Mean } \pm \text { SE) } \\
\text { Hypothyroidism }\end{array}$ & $\begin{array}{l}\text { Mean } \pm \text { SE) } \\
\text { Subclinical } \\
\text { Hypothyroidism }\end{array}$ & $\begin{array}{l}\text { (Mean } \pm \text { SE) } \\
\text { Hyperthyroidism }\end{array}$ & $\begin{array}{l}\text { (Mean } \\
\text { Subclinical } \\
\text { Hyperthyroidism }\end{array}$ & $\begin{array}{l}\text { Mean } \\
\text { SE } \\
\text { Pituitary } \\
\text { defect }\end{array}$ & $\begin{array}{l}\text { P } \\
\text { value }\end{array}$ \\
$\mathrm{fT} 3(\mathrm{pg} / \mathrm{ml})$ & $2.3 \pm 0.6$ & $1.1 \pm 0.7$ & $1.8 \pm 0.5$ & $7.4 \pm 5.6$ & $2.9 \pm 0.8$ & $5.9 \pm 1.7$ \\
\hline $\mathrm{fT}_{4}(\mathrm{pg} / \mathrm{ml})$ & $11.5 \pm 2$. & $4.6 \pm 2.7$ & $9.4 \pm 1.5$ & $25.6 \pm 13.3$ & $13.3 \pm 3.2$ & 20.001 \\
$\mathrm{TSH}(\mu \mathrm{IU} / \mathrm{ml})$ & $2.3 \pm 1.1$ & $31.9 \pm 24.2$ & $7.4 \pm 6.7$ & $0.3 \pm 0.2$ & $0.4 \pm 0.1$ & $9.5 \pm 8.3$ \\
\hline
\end{tabular}

Table3: Comparison of thyroid hormones in different gender

\begin{tabular}{|l|l|l|l|}
\hline Thyroid Hormones & $\begin{array}{l}\text { Male } \\
\text { Mean } \pm \text { SD }\end{array}$ & $\begin{array}{l}\text { Female } \\
\text { Mean } \pm \text { SD }\end{array}$ & P value \\
\hline freeT3 $(\mathrm{pg} / \mathrm{ml})$ & $2.43 \pm 1.44$ & $2.6 \pm 1.77$ & 0.001 \\
\hline free $_{4}(\mathrm{pg} / \mathrm{ml})$ & $11.0 \pm 4.16$ & $11.4 \pm 4.9$ & 0.009 \\
\hline TSH $(\mu \mathrm{IU} / \mathrm{ml})$ & $5.17 \pm 9.84$ & $5.22 \pm 10.5$ & 0.870 \\
\hline
\end{tabular}

\section{Discussion}

In the present study more than half of the subjects are females indicating that more females are suffering from thyroid illness. This finding is supported by few studies (Friedman et al., 1999; Ladenson et al., 2000). The prevalence of thyroid disorders seen in this study was $29.0 \%$. Similar study observed $30 \%$ of the population suffering from thyroid dysfunction in eastern Nepal. This prevalence may be due to geographical locations and pattern of iodine deficiency in these regions (Gelal et al., 2009; Baral et al., 2002; Niafar et al., 2009). The worldwide prevalence of hypothyroidism in various studies shows a remarkable variation and current prevalence ranges from $1 \%$ to $20 \%$ for sub-clinical and $1-2 \%$ for overt hypothyroidism (Aminorroaya et al., 2009). Though hypothyroidism is a common endocrine disorder, frequency and severity of the symptoms vary from patient to patient. Sign and symptoms reflect the numerous organ systems regulated by thyroid hormones No single clinical manifestation specially indicates thyroid dysfunction (Wang et al., 1997).

Prevalence of thyroid dysfunction depends upon methodology, classification of hypothyroidism and community examined by age, ethnicity, gender, geographical distribution and environmental facts including iodine consumption (Baral et al., 2002; Rohil et al., 2010).In a study conducted by Aryal et al, 2010 in Dhulikhel district near Kathmandu valley, the prevalence of thyroid dysfunction was $25 \%$ with Hypothyroidism (8\%), subclinical hypothyroidism (8\%), subclinical hyperthyroidism (6\%) and hyperthyroidism (3\%)( Aminorroaya et al., 2009 ). A study from estern Nepal reported prevalence of hypothyriodism (17.19\%) and hyperthyroidism (13.68\%) among thyroid dysfunction (Baral et al., 2002) These findings support our study, which showed prevalence of thyroid disfunction (29\%) with subclinical hypothyroidism $(17 \%)$, hypothyroidism $(8 \%)$ subclinical hyperthyroidism $(1 \%)$ and hyperthyroidism
(3\%) (Niafar et al., 2009).Studies in developed countries have shown, hypothyroidism tends to increase with age and is more common in women and people with goitre(22 Wang et al., 1997). Hypothyroidism is generally autoimmune in origin, presenting either primary atrophic hypothyroidism or Hashimoto's thyroiditis and rarely pitutary or hypothalamic disorders can result secondary hypothyroidism (Mahato et al., 2013). Although all age group presented with thyroid dysfunction, a higher number of subjects were observed in the age groups of 31-45 years. Hypothyroidism is the most common thyroid disorder in a larger group of population (Tunbridge et al., 1977). One similar study, reported the mean age of patients with thyroid dysfunction to be approximately 39 years, which showed the accumulation and manifestation of disorder symptoms in this age group. Few studies have revealed that incidence of hypothyroidism increases with advancing age (Shaw et al., 2006). In this study also the same trends reported. Children under 15 years have presented with hypothyroidism which may be associated with iodine deficiency disorder or Down's syndrome which ultimately retards physical and mental growth and development (Das et al., 2007).Some studies have reported that obesity, diabetes, Metabolic Syndrome, and depression have association with thyroid dysfunction (Tunbridge et al., 1977).

\section{Conclusion}

This study has revealed the prevalence of thyroid dysfunction typically hypothyroidism and sub clinical hypothyroidism, were higher in central Nepal. Epidemiological studies are needed to establish the accurate prevalence and predominant etiology of thyroid dysfunction in this region of the country. In addition, the role of depression, obesity and diabetes must be extensively studied and explicitly defined. The study recommends thyroid dysfunction screening and treatment campaigning in the general population of Nepal to reduce the burden of disease. The present study has identified the burden of thyroid dysfunction in the central region of Nepal and can 
be used as baseline data for further studies. The prevalence based studies needs to be done to establish the reference intervals of thyroid hormones in Nepalese populations.

\section{Limitations of the study}

The present study is based on serum $\mathrm{fT}_{3} \mathrm{fT}_{4}$ and TSH measurement. Total $\mathrm{T}_{3}, \mathrm{~T}_{4}, \quad$ Thyroglobulin, antithyroperoxidase, anti-thyroglobulin (anti-Tg), TSH receptor antibodies and thyroid stimulating immuniglobulin (TSI) were not included to rule out thyroid disease. The cutoff values of thyroid hormones ( $\mathrm{fT}_{3} \mathrm{fT}_{4}$ and $\mathrm{TSH}$ ) used was those recommended by the manufacturer of the kit, and other related studies as few studies are performed in these regions to establish the reference intervals of thyroid parameters in Nepalese population. This study is hospital based study, so it does not represent the general population.

\section{Acknowledgement}

The authors are grateful to Miss Revika and Renuka Singh for their contribution during data entry. Athors are also grateful to all the staffs of Clinical Biochemistry Laboratory, Tribhuvan University Teaching Hospital, Institute of Medicine, Kathmandu, Nepal.

\section{References}

Aminorroaya A, Janghorbani M, Amini M, Hovsepian S, Tabatabaei A and Fallah Z (2009) The prevalence of thyroid dysfunction in an iodine-sufficient area in Iran. Arch. Iran Med. 12(3): 262-270.

Ashworth L (1996) Medication use in the hypothyroid patient. Home Care Provide. 1: 97

Baral N, Lamsal M and Koner BC (2002). Thyroid dysfunction in eastern Nepal. South Asian J. Trop. Med. Public Health 33: 638-641.

Brownlie BE, Wells JE (1990) The epidemiology of thyrotoxicosis in NewZealand: incidence and geographical distribution in north Canterbury, 1983-1985. Clin. Endocrinology 33: 249-59. DOI: 10.1111/j.1365-2265.1990.tb00489.x

Das BKL, Baral N, Shyangwa PM and et al. (2007) Altered serum levels of thyroxine, triiodothyronine and thyroid stimulating hormone in patients with depression. Kathmandu Univ. Med. J. 5: 330-334.

Friedman MN (1999) Screening for thyroid disease. Ann. Med. 130: 161-162. DOI: http://dx.doi.org/10.7326/0003-4819130-2-199901190-00016

Gelal B, Aryal M, Das BKL, et al. Assessment of io-dine deficiency status among school age children of Nepal by urinary iodine assay. South Asian J Trop Med Public Health 2009; 40: 538- 543.

Helfand M, Redfern CC (1998). Clinical guideline, part 2.Screening for thyroid disease: an update. AmericanCollege of Physician. Ann Intern Med 1998; 129: 144-58. DOI: 10.7326/0003-4819-129-2-19980715000020
International Council for Control of Iodine Deficiency Disorders, UNICEF. World Health Organization (2001) Assessment of iodine deficiency disorders and monitoring their elimination: a guide for programme managers. 2nd ed. Geneva: World Health Organization.

Ladenson Paul W (2000). American thyroid association guidelines for detection of thyroid dysfunction. Arch Intern Med. 160: 1573-1575. DOI: 10.1001/archinte.160.11.1573

Mahato RV, Nepal AK, Gelal B, et al (2013). Spectrum of Thyroid Dysfunction in Patients Visiting Kantipur Hospital, Kathmandu, Nepal. Mymensingh Med. J. 22 (1): 164-169.

Niafar M, Aliasgharzadeh A, Bahrami A and et al. (2009) Prevalence of thyroid dysfunction in the elderly women of Iran. Endocrine Abstracts 2009, 20: 137.

Parle JV, Franklyn JA, Cross KW and et al. (1992) Circulating lipid and minor abnormalities of thyroid function. Clin. Endocrinology 37: 411-414. DOI: 10.1111/j.13652265.1992.tb02351.x

Peter PAS (2009) Epidemiology of Thyroid dysfunctionhypothyroidism and hyperthyroididm. Thyroid International. 2: 1-16.

Risal P, Maharjan BR, Koju R, et al (2010) Variation of total serum cholesterol among the patient with thyroid dysfunction. Kathmandu Univ Med J. 8: 265-268. DOI: http://dx.doi.org/10.3126/kumj.v8i2.3573

Rohil V, Mishra AK, Shrewastawa MK, Mehta KD, Lamsal M, Baral N and et al. (2010). Subclinical hypothyroidism in eastern Nepal: a hospital based study. Kathmandu Univ. Med. J. 8(30): 231-237. DOI: 10.3126/kumj.v8i2.3565

Shaw CK, Thapalia A, Nanda S and Shaw P (2006). Thyroid dysfunction in Down syndrome. Kathmandu Univ. Med.J. 4: 182-186.

Surks MI, Chopra IJ, Mariash CN and et al. (1990). American thyroid association guidelines for use of laboratory tests in thyroid disorders. J A M A 263: 1529-1532. DOI: 10.1001/jama.1990.03440110095035

Tunbridge WMG, Evered DC, Hall R and et al. (1997). The spectrum of thyroid disease in a community: the Whickham survey. Clin. Endocrinol. 7: 481-483. DOI: 10.1111/j.1365-2265.1977.tb01340.x

Vanderpump MP and Tunbridge WM (2002). Epidemiology and prevention of clinical and subclinical hypothyroidism. Thyroid. 12: 839-847. DOI: $10.1089 / 105072502761016458$

Wang C, Crapo LM (1997). The epidemiology of thyroid disease and implications for screening. Endocrinol Metab Clin North Am. 26(1):189-218. DOI: 10.1016/S08898529(05)70240-1

Wiersinga WM (1995) Subclinical hypothyroidism and hyperthyroidism. Prevalence and clinical relevance. Neth J Med. 46:197-204. DOI: 10.1016/0300-2977(94)00089$\mathrm{R}$ 